\title{
ANALISIS LAPORAN REALISASI ANGGARAN KHUSUS KELURAHAN (AKK) 2016- 2017 STUDI KASUS (KELURAHAN ADIARSA BARAT KABUPATEN KARAWANG)
}

\author{
Oleh \\ Sri Suartini \\ Fakultas Ekonomi dan Bisnis Jurusan Akuntansi \\ Universitas Singaperbangsa Karawang \\ srisuartini_daw@yahoo.com \\ DOI Artikel : https://doi.org/10.34308/eqien.v6i2.99
}

\begin{tabular}{l}
\hline Article Info \\
\hline Article History : \\
Received 15 Agustus 2019 \\
Accepted 29 Agustus 2019 \\
Available Online 05 \\
September 2019
\end{tabular}

Keyword :

APBD, Special Village

Budget

\begin{abstract}
$A P B D$ is a plan for the implementation of all Regional Revenues and all Regional Expenditures in the framework of the implementation of Decentralization within a given fiscal year. Collection of all Regional revenues aims to meet the targets set in the APBD. Likewise, all regional expenditures and bonds that burden the regions in the context of the implementation of decentralization are carried out in accordance with the amounts and targets set in the APBD. Because the $A P B D$ is the basis for regional financial management, the APBD also forms the basis for regional financial control, inspection and supervision activities

Basically, the performance budget is a system for preparing and managing regional budgets which are oriented towards achieving results or performance. The performance must reflect the efficiency and effectiveness of public services, which means it must be oriented to the public interest. This has become the need of regional communities to carry out broad, real and responsible autonomy and regional autonomy must be understood as the right or authority of local communities to manage and manage their own affairs. The aspect or role of the regional government is no longer a mere tool of the interests of the central government but rather a tool to fight for regional aspirations and interests.

The method used, the process of collecting data moves from the empirical field in an effort to build theory from the data, the purpose of this study is to find out, understand and analyze how the Reporting and Presentation of 2016-2017 Urban Budget Special Realization (AKK) in Adiarsa Barat District, Karawang Barat District Karawang and analyze how the financial analysis of 2016-2017 Urban Budget Special Realization (AKK) in Adiarsa Barat Village Karawang Barat District Karawang District. By paying attention to these objectives, the research method used is a Quantitative Description Adiarsa Barat Kelurahan shopping performance from T 2016 to T.A 2017 showed good performance. Based on the analysis of the results of the 2016/2017 T.A shopping growth shows there is a growth in spending. Expenditures which most affected the increase in growth in total expenditure were capital and operational expenditure
\end{abstract}




\section{PENDAHULUAN}

Otonomi daerah ditetapkan oleh MPR dengan mengeluarkan ketetapan yaitu Tap MPR Nomor XV/MPR/1998 tentang "Penyelenggaraan Otonomi Daerah: Pengaturan, Pembagian, dan Pemanfaatan Sumber Daya Nasional yang berkeadilan serta berimbang Keuangan Pusat dan Daerah dalam Kerangka Negara Kesatuan Republik Indonesia" merupakan landasan hukum bagi dikeluarkannya undang-undang Nomor 22 Tahun 1999 tentang Pemerintah Daerah, Namun sejalannya waktu yang menyatakan bahwa Undang-undang Nomor 22 Tahun 1999 tentang Pemerintahan Daerah tidak sesuai dengan perkembangan keadaan, ketatanegaraan, dan tuntutan penyelenggaraan otonomi daerah sehingga perlu diganti. Sehingga dikeluarkanlah Undang-undang penggantian yaitu: undang-undang Nomor 32 Tahun 2004 tentang Pemerintah Daerah dan undang-undang Nomor 33 Tahun 2004 tentang Perimbangan Keuangan antara Pemerintah Pusat dan Pemerintah Daerah.

Otonomi Daerah berdasarkan Undang-undang Nomor 32 Tahun 2004 tentang Pemerintahan Daerah adalah hak, wewenang, dan kewajiban daerah otonom untuk mengatur dan mengurus sendiri urusan pemerintahan dan kepentingan masyarakat setempat sesuai dengan peraturan perundang-undangan. Pemberian otonomi secara luas diharapkan dapat mewujudkan kesejahteraan masyarakat melalui peningkatan pelayanan, pemberdayaan, dan peran serta masyakarat. Prinsip otonomi yang nyata dan bertanggung jawab berdasarkan undangundang Nomor 32 Tahun 2004 memberi maksud untuk menangani urusan pemerintahan yang didasarkan oleh tugas, wewenang, dan kewajiban yang nyata, serta benar-benar sesuai dengan tujuan dan maksud pemberian otonomi, yang pada dasarnya untuk memberdayakan daerah, termasuk meningkatkan kesejahteraan rakyat, yang merupakan bagian utama dari tujuan nasional. Pengertian otonomi daerah diatas, menyatakan secara teoretis, desentralisasi memberikan dua manfaat nyata, yaitu pertama, mendorong peningkatan partisipasi, prakarsa, dan kreativitas masyarakat dalam pembangunan, serta mendorong pemerataan hasil-hasil pembangunan (keadilan) di seluruh daerah dengan memanfaatkan sumber daya dan potensial yang tersedia di masing-masing daerah. Kedua, memperbaiki alokasi sumber daya produktif melalui pergeseran peran pengambilan keputusan publik ke tingkat pemerintah yang paling rendah yang memiliki informasi yang paling lengkap.

Pemerintah Daerah merupakan yang mengatur dan mengurus sendiri urusan pemerintahan untuk mempercepat terwujudnya kesejahteraan menurut asas otonomi dan tugas pembantuan. Dalam kenyataan kebangsaan saat ini, perwujudan kesejahteraan masyarakat masih jauh dari yang diharapkan. Kondisi ini terlihat dengan masih terdapatnya masalah kesenjangan sosial yang belum terselesaikan dengan baik. Salah satu masalah sosial yang perlu mendapat perhatian besar dan penanganan serius oleh Pemerintah dan seluruh elemen masyarakat adalah permasalahan kemiskinan.

Secara praktiknya, Pemerintah Daerah dituntut mampu menciptakan sistem manajemen yang mampu mendukung operasionalisasi pembangunan daerah. Salah satu aspek dari pemerintahan daerah yang harus diatur secara hati- hati adalah masalah pengelolaan keuangan daerah dan anggaran daerah. Anggaran Daerah atau Anggaran Pendapatan dan Belanja Daerah (APBD) merupakan instrumen kebijakan yang utama bagi Pemerintah Daerah.

Belanja untuk daerah adalah semua pengeluaran Negara untuk membiayai dana perimbangan, serta dana otonomi khusus dan dana penyesuaian. Dana perimbangan adalah semua pengeluaran Negara yang dialokasikan kepada daerah untuk membiayai kebutuhan daerah dalam rangka pelaksanaan desentralisasi, yang terdiri atas dana bagi hasil, dana alokasi umum, dan dana alokasi khusus, sebagaimana dimaksud dalam Undang-undang Nomor 25 Tahun 1999 tentang Perimbangan Keuangan antara Pemerintah Pusat dan Daerah. (1) Dana bagi hasil (DBH) adalah bagian daerah atas penerimaan pajak bumi dan bangunan, bea perolehan hak atas tanah dan bangunan, dan penerimaan sumber daya alam. (2) Dana alokasi umum (DAU) adalah semua pengeluaran Negara yang dialokasikan kepada daerah dengan tujuan pemerataan kemampuan keuangan antar daerah. (3) Dana alokasi khusus (DAK) adalah semua pengeluaran Negara yang dialokasikan kepada daerah untuk membantu membiayai kebutuhan khusus.

Anggaran Pendapatan dan Belanja Daerah disingkat APBD adalah suatu rencana keuangan tahunan pemerintah daerah yang disetujui oleh Dewan Perwakilan Rakyat 
Daerah (undang-undang Nomor 17 Tahun 2003 pasal 1 butir 8 tentang Keuangan Negara). APBD merupakan dasar pengelolaan keuangan daerah dalam satu tahun anggaran. APBD merupakan rencana pelaksanaan semua Pendapatan Daerah dan semua Belanja Daerah dalam rangka pelaksanaan Desentralisasi dalam tahun anggaran tertentu. Pemungutan semua penerimaan Daerah bertujuan untuk memenuhi target yang ditetapkan dalam APBD. Demikian pula semua pengeluaran daerah dan ikatan yang membebani daerah dalam rangka pelaksanaan desentralisasi dilakukan sesuai jumlah dan sasaran yang ditetapkan dalam APBD. Karena APBD merupakan dasar pengelolaan keuangan daerah, maka APBD menjadi dasar pula bagi kegiatan pengendalian, pemeriksaan dan pengawasan keuangan daerah. Konsekuensi logis pelaksanaan otonomi daerah berdasarkan UU No. 22 tahun 1999 dan UU No. 25 tahun 1999 menyebabkan perubahan dalam manajemen keuangan daerah. Perubahan tersebut antara lain adalah perlunya dilakukan budgeting reform atau reformasi anggaran. yaitu pemendagri Nomor 39 tahun 2017 tentang Kode dan Data Wilayah Administrasi Pemerintahan. Dari peraturan terbaru ini, maka dapat diketahui bahwa di kabupaten Karawang terdapat sebanyak 297 desa dan 12 kelurahan yang tersebar di 30 kecamatan. Dana desa/Kelurahan yang berasal dari dari pemerintah daerah akan digulirkan untuk 297 desa se kabupaten karawang, Jawa Barat, pada Tahun ini mengalami peningkatan yang signifikan dibandingkan dengan tahun sebelumnya, (sumber : kepala badan pemberdayaan masyarakat dan Pemerintahan desa , pada Antara Megapolitan).Beranjak dari hal itu pada tahun 2017 ini Pemerintah Kota karawang menerapkan konsep diadakannya Alokasi Dana Khusus (ADK) Kelurahan. Bentuk dari komitmen tersebut Pemerintah Kota Karawang telah menerbitkan Peraturan Walikota tanggal 2 Januari 2017 perihal Petunjuk Pelaksanan dan Penggunaan Alokasi Dana Khusus Kelurahan di Pemerintah Kota karawang Tahun 2017. Dalam Peraturan Walikota tersebut alokasi tentang Kode dan Data Wilayah Administradina khusus kelurahan merupakan bantuan Pemerintahan, Kabupaten Karawang merupakan salakeuangan dari Pemerintah Kota Karawang satu dari 27 kabupaten / kota atau 18 kabupaten dan 9 kokepada Kelurahan yang berasal dari Anggaran di Provinsi Jawa Barat. Peraturan Tersebut di atas telallendapatan dan Belanja Daerah Kota ditetapkan oleh Menteri Dalam Negeri pada tanggal 2Warawang.

Juni 2017 di Jakarta untuk menggantikan peraturánujuan Penelitian

sebelumnya yang sudah dicabut dan dinyatakan tidakntuk Mengetahui, Memahami dan berlaku yaitu pemendagri Nomor 39 tahun 2017 tentangenganalisis bagaimana Pelaporan Realisasi Kode dan Data Wilayah Administrasi Pemerintahan. Dadian Pelaksanaan Anggaran Khusus Kelurahan peraturan terbaru ini, maka dapat diketahui bahwa (AKK) Tahun 2016-2017 di Kelurahan kabupaten Karawang terdapat sebanyak 297 desa dan 1\&diarsa Barat Kecamatan Karawang Barat kelurahan yang tersebar di 30 kecamatan. AnggardKabupaten Karawang

Dana desa/Kelurahan yang berasal dari dari pemerintah

daerah akan digulirkan untuk 297 desa se kabupatKAJIAN PUSTAKA DAN

karawang, Jawa Barat, pada Tahun ini mengalanPEGEMBANGAN HIPOTESIS

peningkatan yang signifikan dibandingkan dengan tahun Nordiawan (2010:125) sistim akuntansi sebelumnya, (sumber : kepala badan pemberdayaapmemerintahan daerah adalah serangkaian prosedur mulai masyarakat dan Pemerintahan desa , pada Antardari proses pengumpulan data, pencatatan, Megapolitan).

Menurut Peraturan menteri dalam Negeri (Permendagri) Nomor 56 tahun 2017 tentang Kode dan Data Wilayah Administrasi Pemerintahan, Kabupaten Karawang merupakan salah satu dari 27 kabupaten / kota atau 18 kabupaten dan 9 kota di Provinsi Jawa Barat. Peraturan Tersebut di atas telah ditetapkan oleh Menteri Dalam Negeri pada tanggal 29 Juni 2017 di Jakarta untuk menggantikan peraturan sebelumnya yang sudah dicabut dan dinyatakan tidak berlaku pengikhtisaran, sampai dengan pelaporan keuangan dalam rangka pertanggungjawaban pelaksanaan APBD yang dapat dilakukan secara manual atau menggunakan atau menggunakan aplikasi komputer. Mursyidi (2009) menyatakan bahwa akuntansi pemerintahan adalah mekanisme teknik dan analisis akuntansi yang diterapkan pada pengelolaan dana masyarakat dilembaga- lembaga tinggi negara dan depertemendepertemen di bawanya 
Mardiasmo (2004: 62) menyebutkan bahwa anggaran sektor publik didefinisikan menjadi: "Anggaran publik berisi rencana kegiatan yang direpresentasikan dalam bentuk rencana perolehan pendapatan dan belanja dalam suatu moneter. Dalam bentuk yang paling sederhana, anggaran publik merupakan suatu dokumen yang menggambarkan kondisi keuangan dari suatu organisasi yang meliputi informasi mengenai pendapatan, belanja, dan aktivitas.

Menurut Mulyadi (2011:488), anggaran merupakan suatu rencana kerja yang dinyatakan secara kuantitatif yang diukur dalam satuan moneter standar dan satuan ukuran yang lain yang menvakup jangka waktu satu tahun.

\section{Menurut Supriyono (2009: 15),} penganggaran merupakan perencanaan keuangan perusahaan yang dipakai sebagai dasar pengendalian (pengawasan) keuangan perusahaan untuk periode yang akan datang Keberadaan kelurahan secara yuridis formal diakui di dalam Peraturan Pemerintah Nomor 73 Tahun 2005 tentang Kelurahan. Berdasarkan ketentuan ini Kelurahan adaalah wilayah kerja Lurah sebagai perangkat daerah Kabupaten/Kota dalam wilayah kerja kecamatan. Pemahaman kelurahan tersebut menempatkan kelurahan sebagai suatu organisasi pemerintahan yang secara politis memiliki kewenangan tertentu untuk mengurus dan mengatur warga atau komunitasnya. Posisi tersebut membuat kelurahan memiliki peran yang sangat penting dalam menunjang kesuksesan jalannya roda pemerintahan. Kelurahan menjadi garda terdepan dalam menggapai keberhasilan dari segala urusan dan program dari pemerintah.

Analisis Kinerja Keuangan Pemerintah Daerah Dalam pasal 5 Peraturan Pemerintah Nomor 1052000 disebutkan bahwa APBD merupakan dasar pengelolaan keuangan daerah dalam tahun anggaran tertentu. Ketentuan ini berarti untuk mengetahui kinerja keuangan pemerintah daerah dapat dilihat dari keberhasilan pemerintah daerah dalam melaksanakan APBD yang ditetapkan. Kinerja merupakan gambaran mengenai tingkat pencapaian pelaksanaan sesuatu kegiatan/program/kebijaksanaan dalam mewujudkan sasaran, tujuan, misi dan visi organisasi perlu dilakukan untuk mengetahui tingkat keberhasilan yang telah dicapai dan untuk membuat program perbaikan apabila diperlukan.

Analisis Rasio Keuangan Dalam menilai kinerja suatu entitas diperlukan alat untuk menganalisis laporan keuangannya, salah satu alat yang sering digunakan adalah analisis rasio terhadap laporan keuangan.

Warti siti (2019) berpendapat Persentase alokasi realisasi belanja operasi sangat besar agar dapat dilakukan perimbangan antara belanja modal dan belanja operasi.

Runic Puji ( 2016 ) Dengan Analisis Varians dapat menghemat setiap tahunnya dan efektivitas PAD Belanja, dan Rasio Efisiensi Belanja.Seperti halnya dalam Rasio Efisiensi Belanja

Rukayah (2017) dalam pengelolaan Belanja Operasi dan Belanja Modalnya. Perlu untuk diperhatikan oleh Pemerintah Daerah walaupun patokan untuk besarnya Belanja Operasional dan Belanja Modal terhadap APBD belum ada, namun sebagai daerah yang berada di Negara Berkembang Pemerintah Daerah seharusnya meningkatkan Belanja Modal (pembangunan) dalam menyediakan sarana prasarana yang mendukung untuk peningkatan kesejahteraan masyarakat dan pelayanan publik.

Ramlah basri (2017 ) Penyusunan anggaran dimulai dari pengumpulan data dari bidang mengenai program/kegiatan yang akan dilaksanakan didasarkan pada Rencana Strategis (RENSTRA) sebagai tolak ukur dan alat bantu dalam melaksanakan tugas dan fungsi

\section{METODE PENELITIAN}

Berdasarkan pengelompokan data tersebut, maka data yang digunakan dalam penelitian ini adalah data kuantitatif. Adapun tujuan dari penelitian ini adalah untuk mengungkapkan kejadian atau fakta, keadaan, fenomena, variabel dan keadaan yang terjadi saat penelitian berlangsung dengan menyuguhkan apa yang sebenarnya terjadi. Penelitian ini menafsirkan dan menguraikan data yang bersangkutan dengan situasi yang sedang terjadi, sikap serta pandangan yang terjadi di dalam suatu masyarakat, pertentangan antara dua keadaan atau lebih, hubungan antar variable yang timbul, perbedaan antar fakta yang ada serta pengaruhnya terhadap suatu kondisi. 
Tujuan penelitian ini untuk Untuk Mengetahui, Memahami dan menganalisis bagaimana Pelaporan dan Penyajian Realisasi Anggaran Khusus Kelurahan (AKK) 2016-2017 di Kelurahan Adiarsa Barat Kecamatan Karawang Barat Kabupaten Karawang dan menganalisis bagaimana Analisis keuangan Realisasi Anggaran Khusus Kelurahan (AKK) 2016-2017 di Kelurahan Adiarsa Barat Kecamatan Karawang Barat Kabupaten Karawang. Dengan memperhatikan tujuan tersebut, maka metode penelitian yang digunakan adalah Deskripsi Kuantitatif.

\section{Variabel Penelitian}

Variabel secara sederhana dapat diartikan ciri dan individu, objeck, segala peristiwa yang dapat diukur secara kuantitatif/kualitatif. Sedangkan definisi operasional merupakan pengubahan konsep yang masih berupa abstrak dengan kata-kata yang menggambarkan prilaku yang dapat diuji dan ditentukan kebenarannya oleh orang lain berdasarkan variabel yang digunakan (Nurmayasari 2010).

\section{Metode Pengumpulan Data}

Dalam penelitian kualitatif, proses pengumpulan data bergerak dari lapangan empiris dalam upaya membangun teori dari data. Adapun teknik pengumpulam data alam peneliti ini adalah sebagai berikut:

1. Wawancara mendalam (in depth interview), dilakukan untuk mendapatkan informasi/data empiris. Wawancara adalah percakapan dengan maksud tertentu. Percakapan itu dilakukan oleh dua pihak, yaitu pewawancara (interviewer) yang mengajukan pertanyaan dan yang di wawancarai (interviewee) yang memberikan jawaban atas pertanyaan itu (Moleong, 2002:133).

2. Metode Observasi adalah metode pengumpulan data dengan jalan mengamati suatu fenomena secara langsung. Dalam menggunakan metode observasi cara yang paling efektif adalah melengkapinya dengan sistematis terhadap apa yang diteliti (Nurkancana, 2006:18). Sedangkan menurut pendapat Arikunto adalah: Metode observasi atau yang disebut dengan pengamatan meliputi, kegiatan pemusatan perhatian terhadap kejadian dengan menggunakan metode observasi (2007:204). Berdasarkan kedua pendapat di atas maka dapat disimpulkan bahwa yang dimaksud dengan metode observasi adalah suatu penelitian atau penyelidikan yang dilakukan dengan cara mengamati langsung gejalagejala yang akan diteliti. Adapun permasalahan yang akan diobservasi oleh peneliti adalah berkaitan dengan Pengalokasian dana desa dalam Meningkatkan Pemberdayaan Masyarakat serta pertanggungjawaban kinerja aparatur Pemerintah Desa termasuk di dalamnya Kepala Desa

3. Metode Dokumentasi, Menurut Abdurrahim metode dokumentasi adalah suatu tehnik atau cara dalam mengumpulkan data dengan melalui dokumen atau catatan yang diperlukan dalam penelitian (2007:26). Berdasarkan pendapat di atas bahwa yang dimaksud dengan metode dokumentasi dalam penelitian ini adalah mengumpulkan dan mencari dokumen-dokumen tentang kegiatan pelaksanaan Pengalokasian dana desa di Desa Adiarsa Barat Kecamatan Karawang Barat Kabupaten Karawang. yang ada kaitannya dengan penelitian ini. Adapun data-data yang akan diambil oleh peneliti adalah Peraturan Desa, klasifikasi tingkat

\section{HASIL DAN PEMBAHASAN}

Laporan Realisasi Anggaran Khusus Kelurahan Tahun 2016 dan 2017 di Kelurahan Adiarsa Barat Kecamatan Karawang Barat Kabupaten Karawang ,Pengelolaan Sumber pendapatan kelurahan berdasarkan Peraturan Pemerintah Nomor 73 Tahun 2005 tentang kelurahan, pasal 9 ayat (1) bahwa keuangan kelurahan bersumber dari: a) APBD (anggaran Pendapatan Belanja daerah) Kabupaten/Kota yang dialokasikan sebagaimana perangkat daerah lainnya; b) Bantuan pemerintah, pemerintah provinsi, pemerintah kabupaten/kota dan bantuan pihak ketiga; c) Sumber-sumber lain yang sah dan tidak mengikat. Sesuai dengan pasal 9 ayat (2) Peraturan Pemerintah nomor 73 Tahun 2005 tentang kelurahan menyatakan bahwa alokasi anggaran kelurahan yang berasal dari APBD (anggaran Pendapatan Belanja daerah) Kabupaten/Kota sebagaimana dimaksud pada pasal 9 ayat (1) huruf a di atas, memperhatikan faktor-faktor sekurang-kurangnya yaitu jumlah penduduk, kepadatan penduduk, luas wilayah, kondisi geografis/karakteristik wilayah, jenis dan volume pelayanan serta besaran pelimpahan tugas yang diberikan. Ketentuan pasal tersebut mengamanatkan kepada Pemerintah Kabupaten untuk mengalokasikan dana perimbangan yang diterima kabupaten 
kepada kelurahan dengan memperhatikan prinsip keadilan dan menjamin adanya pemerataan.

Laporan realisasi anggaran pendapatan dan belanja daerah Di Kelurahan Adiarsa Barat tahun anggaran 2016 dan tahun 2017 sesuai dengan Peraturan Pemerintah Karawang Nomor 12 Tahun 2010.

Dari hasil penelitian yang dilakukan di Kelurahan Adiarsa Barat berdasarkan Laporan Realisasi Anggaran Tahun 2016 sampai dengan tahun 2017 dengan hasil analisis keuangan tahun 2016-2017 menunjukan kinerja yang baik, dimana terdapat selisih anggaran belanja dengan realisasi yang bersaldo negatif yaitu: T.A 2016 sebesar Rp 68.678.609,00 atau 7,22 \% dari total Anggaran, dan untuk T.A 2017 sebesar Rp33.226.998,00 atau 2,73\% dari total Anggaran Hasil analisis pertumbuhan belanja untuk tahun anggaran 2016 adalah sebesar Rp 268.056.900 atau 11,35\%. Dari hasil analisis keserasian maka dapat diketahui Kelurahan Adiarsa Barat dalam melakukan aktifitas belanjanya, tidak hanya memfokuskan belanja pada belanja operasi saja tetapi juga kepada belanja modal . Hanya saja, perbedaan dari kedua aktivitas belanja tersebut adalah aktifitas belanja operasi jauh lebih besar dari pada aktifitas belanja modal.

Keseluruhan penelitian ini dilakukan di Keluraha Adiarsa Barat,berdasarkan Laporan Realisasi Anggaran Khusus Kelurahan (AKK) Tahun 2016-2017 sebagai berikut: T.A 2016 realisasi belanja sebesar $92.78 \%$ dan T.A 2017 sebesar $97.27 \%$ dari yang dianggarkan. Hal ini menunjukan adanya kinerja belanja daerah yan baik yaitu dengan adanya efisiensi belanja untuk tahun anggaran 2016 sebesar $12.73 \%$ dan tahun anggaran 2017 sebesar $14.60 \%$. Secara umum seluruh komponen belanja, baik belanja operasi maupun belanja modal menunjukan kinerja yang baik, dimana terdapat efisiensi yang memadai terlebih lagi untuk tahun anggaran 2016. Lampiran Rincian LRA menunjukan presentase belanja operasional lebih besar dari total belanja daerah dibandingkan dengan belanja modal. Dengan demikian dapat dilihat bahwa kelurahan Adiarsa Barat lebih memprioritaskan dananya pada beanja operasi dibandingkan belanja modal.

Belum ada tolak ukur yang pasti berapa besarnya rasio belanja operasi maupun belanja modal terhadap APBD yang ideal, karena sangat dipengaruhi oleh dinamisasi kegiatan pembangunan dan besarnya kebutuhan investasi yang diperlukan untuk mencapai pertumbuhan yang ditargetkan. Sebagai daerah di negara berkembang, peranan Pemerintah Kota untuk memacu pelaksanaan pembangunan relatif besar. Oleh karena itu, rasio belanja modal yang masih kecil perlu ditingkatkan sesuai dengan kebutuhan pembangunan di Kota Karawang.

Pada anggaran tahun 2017 untuk belanja operasi menurun, yaitu anggaran yang digunakan lebih besar dibanding dengan perealisasian dana untuk Belanja operasi, akan tetapi persentase untuk tahun2016 bisa mencapa $81,7 \%$ berbeda dengan tahun 2017 yang hanya menembus $73,71 \%$ maka perealisasian lebih banyak di tahun 2017 yang hampir menyentuh angka anngaran.

Rata-rata rasio Keserasian Belanja pertahunnya sebesar 77,70\% untuk rasio Keserasian Belanja Operasi dan 22,24\% untuk rasio Keserasian Belanja Modal. Selama 2016 dan 2017 diperoleh bahwa rasio Keserasian Belanja Operasi dari tahun ke tahun semakin menurun. Pada tahun 2016 rasio Belanja Operasi yang dicapai sebesar 77,70\%. Pada tahun 2017 rasio Belanja Operasi yang dicapai sebesar 22,24\% mengalami penurunan sebesar $55,46 \%$ dari tahun sebelumnya. Penurunan ini terjadi karena berkurangnya alokasi dana untuk Belanja Operasi dari 1219.031.600 menjadi 904.374.700, hal ini menunjukkan kemampuan pemerintah daerah dalam mencukupi kebutuhan Belanja Operasi untuk melakukan tugas-tugas pemerintahan, dan pelayanan masyarakat sosial sudah cukup baik tetapi harus lebih ditingkatkan kembali agar lebih baik lagi. Rasio Keserasian Belanja Modal selama tahun 2016 dan 2017 mengalami peningkatan dari tahun ke tahun. Pada tahun 2017 rasio belanja modal sebesar $92,35 \%$. Pada tahun 2012 rasio belanja modal yang dicapai $92,37 \%$ hanya mengalami peningkatan sebesar $0,2 \%$ saja. Peningkatan ini terjadi karena bertambahnya dana alokasi untuk Belanja Modal dari 173120000 (lrkp 2017 stlh perubahan) menjadi 320470000 walaupun hanya sedikit ini menunjukkan bahwa rasio belanja modalterhadap APBD Kinerja Keuangan pemerintah mengalami kenaikan untuk menjadi lebih baik.

Rasio Efisiensi Belanja Kelurahan Adiarsa Barat Tahun 2016 sebesar 92,77\% dan pada Tahun 2017 Rasio Efisiensi Belanja Kelurahan Adiarsa Barat Tahun 2017 sebesar 97,27\%, hal 
ini menunjukkan rasio Efisiensi Belanja pada tahun 2016-2017 berada > 90\%-100\%, maka hal ini mengindikasikan Kinerja Keuangan belanja kelurahan Adiarsa Barat Kabupaten karawang yang sudah baik tetapi harus ditingkatkan kembali. Adapun hasilnya yan dapat kita lihat bahwa pada tahun 2017 terlihat 97,77\% ini lebih besar dibandingkan tahun sebelumnya, maka untuk 2017 anggaran lebih boros dibandingkan tahun sebelumnya.

\section{SIMPULAN DAN SARAN}

Berdasarkan Penelitian yang telah dilakukan maka simpulan yang dapat diperoleh mengenai Analisis Laporang Realisasi Anggaran Khusus Kelurahan(AKK) Tahun 2016-2017 (Studi kasus Kelurahan Adiarsa Barat Kabupaten Karawang Barat) adalah Sebagai berikut :

1. Berdasarkan Laporan Realisasi Anggaran T.A 2016 sampai dengan T.A 2017 masing-masing adalah sebagai berikut: T.A 2016 realisasi belanja sebesar $92.78 \%$ dan T.A 2017 sebesar $97.27 \%$ dari yang dianggarkan. Hal ini menunjukan adanya kinerja Belanja daerah yang baik yaitu dengan adanya

efisiensi belanja untuk tahun anggaran 2016 sebesar $7.22 \%$ dari total Anggaran, dan untuk T.A 2017 sebesar $2.73 \%$ dari total Anggaran. Secara umum seluruh komponen belanja, baikbelanja operasi maupun belanja modal menunjukan kinerja yang baik, terdapat efisiensi yang memadai terlebih lagi untuk tahun anggaran 2017.

2. Dari analisis varians belanja dapat diketahui bahwa kinerja belanja Kelurahan Adiarsa Barat dari T.A 2016 sampai dengan T.A 2017 menunjukan kinerja yang baik.berdasarkan analisis hasil pertumbuhan belanja T.A 2016/2017 menunjukan adanya pertumbuhan belanja. Belanja yang paling mempengaruhi kenaikan pertumbuhan jumlah belanja adalah belanja modal dan operasional. Berdasarkan erdasarkan Dari hasil analisis keserasian maka dapat diketahui kelurahan Adiarsa Barat dalam melakukan aktifitas belanjanya, tidak hanya memfokuskan belanja pada belanja operasi akan tetapi juga kepada belanjamodal. Hanya saja, perbedaan dari kedua aktifitas bel anja tersebut adalah aktifitas belanja operasi jauh lebih besar dari pada aktifitas belanja modal. Besarnya selisih ratarata rasio belanja operasi terhadap total belanja dengan rasio belanja modal terhadap total belanja adalah $0.2134 \%$ pertahun.Dari hasil perhitungan rasio efisiensi belanja, maka dapat dilihat T.A 2016 sampai T.A 2017 Kelurahan Adiarsa Barat dapat melakukan penghematan anggaran. T.A 2016 sebesar Rp 68.678.609,00 atau 13,8\% dari total Anggaran, dan untuk T.A 2017 sebesar Rp33.226.998,00 atau 3,60\%. Berdasarkan Laporan Realisasi Anggaran T.A 2016 sampai dengan T.A 2017 masing-masing adalah sebagai berikut: T.A 2016 realisasi belanja sebesar $92.78 \%$ dan T.A 2017 sebesar $97.27 \%$ dari yang dianggarkan. Hal ini menunjukan adanya kinerja belanja daerah yang baik yaitu dengan adanya efisiensi belanja untuk tahun anggaran 2016 sebesar 7.22\% dan tahun anggaran 2017 sebesar $2.73 \%$. Secara umum seluruh komponen belanja, baik belanja operasi maupun belanja modal menunjukan kinerja yang baik, terdapat efisiensi yang memadai terlebih lagi untuk tahun anggaran 2016.

\section{Saran}

Berdasarkan Simpulan diatas, maka penulis dapat menemukan beberapa hal yang diharapkan dapat dijadikan bahan pertimbangan dan perbaikan dalam Pelaporan Laporan Realisasi Anggaran Khusus Kelurahan (AKK) tahun 2016-2017 pada kelurahan Adiarsa Barat untuk masa yang akan datang sebagai berikut:

1. Melalui penelitian ini diharapkan dapat memberikan masukan bagi pihak-pihak yang terkait dengan pengelolaan belanja daerah secara khusus dan APBD secara umum. Kiranya penelitian ini dapat menjadi bahan acuan bagi penelitian selanjutnya, agar dapat meneliti kinerja belanja secara lebih rinci terhadap Laporan Realisasi Anggaran (LRA). Sehingga akan selalu ada perubahan kearah yang lebih baik.

Semakin meningkatkan kinerja dalam pengelolaan belanja daerah secara khusus dan APBDsecara umum. Dengan kinerja yang baik maka efektifitas, produktifitas dan efisiensi belanja juga akan semakin baik.Perlu adanya perhatian lebih dari kelurahan Adiarsa Barat terhadap belanja modal, karena dengan belanja modal yang digunakan untuk aset-aset tetap akanberguna dalam jangka panjang dan memberikan manfaat pada masa yang akan datang.Sebagai daerah di negara berkembang, peranan Pemerintah Kota untuk memacu pelaksanaan pembangunan relatif besar. danlebih memprioritaskan dananya pada belanja operasi dibandingkan pada belanja modal. Oleh karena itu, perlu adanya perhatian 
lebih dariKelurahan Adiarsa Barat terhadap belanja modal, karena dengan belanja modal yang digunakan untuk aset-aset tetap akan berguna dalam jangka panjang dan dapat memberikan manfaat pada masa yang akan datang.

\section{REFERENSI}

Abdul Halim, 2007,Akuntansi Keuangan Daerah Edisi 3(Jakarta:Salemba Empat)

Abdul Halim, Muhammad Syam Kusufi, 2014, Teori, Konsep, dan Aplikasi Akuntansi Sektor Publik (Jakarta:Salemba Empat)

Amirullah Haris Budiyono, 2004, Pengantar Manajemen(yogyakarta:Graha ilmu)

Deddi Nordiawan, Ayuningtyas Hertianti, 2010, Akuntansi Sektor Publik Edisi 2 (Jakarta:Salemba Empat)

Mardiasmo, 2009, Akuntansi Sektor Publik (Yogyakarta:Andi)

Nur Afiah, 2010, Implementasi Akuntansi Keuangan Pemerintah Daerah

Sedarmayanti, 2009, Sumberdaya Manusia dan Produktivitas Kerja

Sholeh, Chabib, Suripto, 2011, Menilai Kinerja Pemerintah Daerah (Bandung:Fokus

Media)

Sugiyono, 2012, Metode Penelitian Pendidikan. Pendekatan Kuantitatif, Kualitatif dan

R\&D (Bandung:Alfabeta)

Suyana Utama, 2008, Rasio Efektivitas dan Efisiensi

Anastasia F. Palilingan, H. Sabijono, L. Mawikere, 2015, Analisis Kinerja Belanja Dalam

Laporan Realisasi Anggaran (LRA) Pada Dinas Pendapatan Kota Manado

A.N.J. Dien, J. Tinangon., S. Walandouw, 2015, Analisis Laporan Realisasi Anggaran

Untuk Menilai Kinerja Keuangan Pada Kantor Dinas Pendapatan Daerah Kota Bitung

Kinerja Keuangan Pada Rumah Sakit Umum Daerah (RSUD) Bangli

Joko Pramono, 2014, Analisis Rasio Keuangan Untuk Menilai Kinerja Keuangan
Pemerintah Daerah (Studi Kasus Pada Pemerintah Kota Surakarta)

Ramlah Basri 2013 Analisis Penyusunan Anggaran Dan Laporan Realisasi Anggaran Pada BPM -PD Provinsi Sulawesi Utara . ISSN 2303-1174 Jurnal EMBA Vol.1 No.4 Desember 2013, Hal. 202-212

Anasta (2015) Analisis Kinerja Belanja Dalam Laporan Realisasi Anggaran (Lra) Pada Dinas Pendapatan Kota Manado . ISSN 2303-1174 Jurnal EMBA Vol.3 No.1 Maret 2015, Hal. 17-25

Sakina Putri 2018 Analisis Kinerja Anggaran Belanja Pada Dinas Kebudayaan Daerah Istimewa Yogyakarta Tahun 2012 - 2016 Jati: Jurnal Akuntansi Terapan Indonesia Vol 1 No 1 Hal 27-37 Maret 2018

Al Makka, Harry. 2015. Analisis Kinerja Belanja Daerah dalam Laporan Realisasi Anggaran pada Dinas Pendapatan Pengelolaan Keuangan dan Aset Daerah di Kota Kotamobagu. Jurnal Berkala Ilmiah Efisiensi, Volume 15 No. 04 Tahun 2015.

Anonim. 2005. Peraturan Pemerintah No.24 Tahun 2005 Tentang Standar Akuntansi Pemerintahan. Bandung:

Fokusmedia. 2012. Peraturan Pemerintah No.71 Tahun 2010 tentang Standar Akuntansi Pemerintahan. Bandung: Fokusmedia.

Arif, Muchlis Bahtiar dan Iskandar. 2009. Akuntansi Pemerintahan. Jakarta: Akademia. Bastian, Indra. 2010. Akuntansi Sektor Publik Suatu Pengantar, Edisi Ketiga. Jakarta: Erlangga.

Halim, Abdul dan Muhammad Syam Kusufi. 2013. Akuntansi Sektor Publik: Akuntansi Keuangan Daerah, Edisi 4. Jakarta: Salemba Empat.

Halim, Abdul, Yanuar E. Restianto dan I Wayan Karman. 2010. Sistem Akuntansi Sektor Publik. Yogyakarta: UPP STIM YKPN.

Harahap, Sofyan Syafri. 2013. Analisis Kritis Atas Laporan Keuangan, Cetakan Kesebelas. Jakarta: Penerbit Rajawali Pers.

Huda, Nurul dkk. 2012. Keuangan Publik Islam: Pendekatan Teoritis dan Sejarah. Jakarta: Kencana.

Kuncoro, Mudrajad. 2009. Metode Riset Untuk Bisnis dan Ekonomi. Edisi Ketiga. Jakarta: Erlangga. 
Mahmudi. 2010. Analisis Laporan Keuangan Pemerintah Daerah. Yogyakarta: Unit Penerbit dan Percetakan STIM YKPN.

Mardiasmo. 2009. Akuntansi Sektor Publik. Yogyakarta: Andi Offset.

Mahsun, Muhamad. 2009. Pengukuran Kinerja Sektor Publik. Yogyakarta: BPFE. Palilingan, Anastasia Friska. 2015. Analisis Kinerja Belanja Dalam Laporan

Akuntabilitas Kinerja Instansi Pemerintahan pada Dinas Pendapatan Kota Manado. Jurnal EMBA, Vol.3 No.1 Maret 2015, Hal. 17-25, ISSN 2303-1174.

Rodiansyah. 2017. Analisis Laporan Akuntabilitas Kinerja Instansi Pemerintah pada Dinas Pekerjaan Umum Kabupaten Berau. Skripsi. Sekolah Tinggi Ilmu Ekonomi Muhammadiyah Tanjung Redeb, Berau.

Rukayah. 2017. Analisis Laporan Realisasi Anggaran dengan Menggunakan Rasio Efektivitas dan Rasio Efisiensi pada Kantor Badan Perijinan Terpadu dan Penanaman Modal Kabupaten Serang. Jurnal Akuntansi. Vol 4 No. 2 Juli 2017, p- ISSN 2339-2436, e-ISSN 2549-5968.

Pemendagri, Tahun 2007, No. 56, Anggaran Pendapatan Dan Belanja Daerah UU No. 32, Tahun 2004, Otonomi Daerah

UU No. 33, Tahun 2004, Perimbangan Keuangan Antara Pemerintah Pusat dan Daerah

Mahmudi. (2007). Analisis Laporan Keuangan Pemerintah Daerah. Yogyakarta: UPP STIM YKPN.

Mahsun, M. (2016). Pengukuran Kinerja Sektor Publik. Yogyakarta: BPFE.

Mardiasmo. (2007). Akuntansi Sektor Publik. Yogyakarta: Andi Offset.

Pangkey, I. \& Pinatik, S. (2015). Analisis Efektivitas dan Efisiensi Anggaran Belanja pada Dinas Kebudayaan dan Pariwisata Provinsi Sulawesi Utara. Jurnal EMBA, 3(4), 33-43.

Kuncoro, Mudrajat. 2009. Metode Riset Untuk Bisnis dan Ekonomi.Bagaimana Meneliti dan Menulis Tesis Edisi 3. Penerbit Erlangga. Jakarta.
Nordiawan Deddi, Ayuningtyas. 2010. Akuntansi Sektor Publik Edisi 2. Penerbit Salemba Empat. Jakarta.

Pemerintah Republik Indonesia. 2006. Peraturan Mentri Dalam Negeri Nomor 13. Tentang Pengelolaan Keuangan Negara. Jakarta

Sugiyono. 2008. Metode Penelitian Bisnis. Cetakan ke dua belas. Penerbit Alfabeta. Bandung

Republik Indonesia, Undang-Undang No. 23

Tahun 2014, 2014Tentang Pemerintah Daerah.

Republik Indonesia, Undang-Undang No. 33 Tahun 2004, 2004.Tentang Perimbangan Keuangan antara Pemerintah Pusat dan Daerah.

Republik Indonesia, Peraturan Pemerintah No. 71 Tahun 2010, 2010.Tentang Standar Akuntansi Pemerintahan

.135

Republik Indonesia, Peraturan Pemerintah No. 58 Tahun 2005, 2005.Tentang Pengelolaan Keuangan Daerah

Sugiyono. 2013. Metode Penelitian Bisnis. Penerbit Alfabeta: Bandung.

Tanjung, Abdul Hafiz 2008.Akuntansi Pemerintah Daerah. Alfabeta: Bandung.

Runik Puji Rahayu 2016 Analisis Atas Laporan Realisasi Anggaran Untuk Mengukur Kinerja Keuangan Pemerintah Kabupaten Pamekasan Makro, Jurnal Manajemen \& Kewirausahaan, Volume 1 No.01 | Mei 2016 ISSN 1412-2936

Warti Siti Analisis Kinerja Belanja Dalam Laporan Realisasi Anggran Pada Dinas Social Kabupaten Berau -ISSN : 26151871 e-ISSN : 2615-5850 Volume 2 Nomor 1, Maret 2019 JEMMA | JURNAL OF ECONOMIC, MANAGEMENT AND ACCOUNTING 